\title{
A SIMPLIFIED METHOD FOR DETECTING THE HEAT-LABILE ENTEROTOXIN OF ESCHERICHIA COLI
}

\author{
P. A. Chapman and Deborah L. Swift
}

Public Health Laboratory, Northern General Hospital, Herries Road, Sheffield S5 7 AU

\begin{abstract}
SUMMARY. A tissue-culture method is described that is suitable for screening large numbers of Escherichia coli isolates for heat-labile enterotoxin production. The method uses readily available laboratory media for culture of the $E$. coli and does not require cell-free extracts. Antibiotics are used to increase toxin production to levels that allow cultures from several different colonies to be pooled for testing, thus minimising the number of tissue-culture monolayers required. Y1 mouse adrenal cells are used in microplate cultures. The method is simple, sensitive and economical and is suitable for use in a routine diagnostic microbiology laboratory.
\end{abstract}

\section{INTRODUCTION}

Enterotoxigenic strains of Escherichia coli are important causes of diarrhoea in travellers from developed to less developed countries (Rowe, 1979; Gross, Scotland and Rowe, 1979; Gross, 1983). Two different toxins may be produced: (1) the heat-labile enterotoxin (LT), which is similar in action and in biological properties to the enterotoxin of Vibrio cholerae, and (2) the unrelated heat-stable toxin (ST). Some strains produce $\mathrm{LT}$ only $\left(\mathrm{LT}^{+} \mathrm{ST}^{-}\right)$, many produce both $\mathrm{LT}$ and $\mathrm{ST}\left(\mathrm{LT}^{+} \mathrm{ST}^{+}\right)$and relatively few produce ST only $\left(\mathrm{LT}^{-} \mathrm{ST}^{+}\right)$(Rowe, 1979). Detection of ST is at present possible only by animal inoculation, though immunological methods are being developed (Honda et al., 1981 b; De Mol et al., 1983). In contrast, LT may be detected by various in-vitro methods, of which tissue-culture assays are the most sensitive (Donta, Moon and Whipp, 1974; Guerrant et al., 1974; Speirs, Stavric and Konowalchuk, 1977).

The aim of this study was to develop a simple, economical tissue-culture method for the detection of LT, suitable for use in a routine diagnostic microbiology laboratory.

\section{MATERIALS AND METHODS}

Control organisms. Known $\mathrm{LT}^{+}$and $\mathrm{LT}^{-}$strains of $E$. coli $\left(\mathrm{O} 148 . \mathrm{H} 28, \mathrm{LT}^{+} \mathrm{ST}^{+}\right.$and O1.H7, $\mathrm{LT}^{-} \mathrm{ST}^{-}$) were supplied by the Division of Enteric Pathogens, Central Public Health Laboratory, Colindale, London.

Media tested for ability to support LT production. Each of the control organisms was grown for $24 \mathrm{~h}$ at $37^{\circ} \mathrm{C}$ in five broth media. These were: (1) glucose syncase medium (GS) (Finkelstein et al., 1966); (2) Tryptone Soya Broth (TS) (Oxoid); (3) TS medium with lincomycin $90 \mu \mathrm{g} / \mathrm{ml}$ and 
the addition of polymyxin $100 \mu \mathrm{g} / \mathrm{ml}$ after incubation for $20 \mathrm{~h}$ (TSLP); (4) Brain Heart Infusion Broth (Oxoid) with casamino acids (Gibco) $2 \%(\mathrm{BH})$; and (5) $\mathrm{BH}$ medium with lincomycin and polymyxin as in TSLP (BHLP). Production of LT in each of these media by the control organisms was determined on three or more occasions by the assay method described below in tests with cell-free extracts (produced by centrifugation and membrane filtration of the supernate) and with crude cultures.

Test strains of E. coli. These were obtained by plating directly on to MacConkey agar faecal samples from 150 patients with diarrhoea who had recently returned from abroad. From each culture, four characteristic lactose-fermenting colonies were examined, individually and as a pooled culture seeded with the four colonies, for LT-production. They were grown in BHLP medium, and were examined as cell-free extracts and crude cultures.

Tissue-culture monolayers. Y1 mouse adrenal cells at a concentration of $200000 \mathrm{cells} / \mathrm{ml}$ of growth medium were seeded in $0.1-\mathrm{ml}$ amounts into sterile flat-bottomed microplates (Flow Laboratories Ltd, Irvine, Ayrshire KA12 $8 \mathrm{NB}$ ) with lids and incubated at $37^{\circ} \mathrm{C}$ in air containing $\mathrm{CO}_{2} 6 \%$. When cells were confluent, growth medium was removed and replaced by maintenance medium and monolayers were used for toxin assay within 5 days.

Y1 cell growth medium. This was Ham's F10 medium with bicarbonate and L-glutamine (Flow Laboratories), supplemented with fetal bovine serum 12\%, penicillin 100 units $/ \mathrm{ml}$ and streptomycin $100 \mu \mathrm{g} / \mathrm{ml}$.

Y1 cell maintenance medium. This was Ham's F10 medium with bicarbonate (Flow Laboratories), supplemented with fetal bovine serum $1.5 \%$, penicillin $100 \mathrm{units} / \mathrm{ml}$, streptomycin $100 \mu \mathrm{g} / \mathrm{ml}$ and amphotericin B $40 \mu \mathrm{g} / \mathrm{ml}$.

Toxin assay. The maintenance medium was removed from a fully confluent cell monolayer and replaced with $0.1 \mathrm{ml}$ of E.coli BHLP culture (cell-free extract or crude culture; undiluted or diluted), and the plate was left at $37^{\circ} \mathrm{C}$ for $30 \mathrm{~min}$. The culture was then removed and replaced by maintenance medium. The monolayer was incubated at $37^{\circ} \mathrm{C}$ for $24 \mathrm{~h}$ and examined for the characteristic rounding of cells caused by LT. The highest dilution of a culture that gave such an effect in more than $75 \%$ of the cells was recorded as the titre.

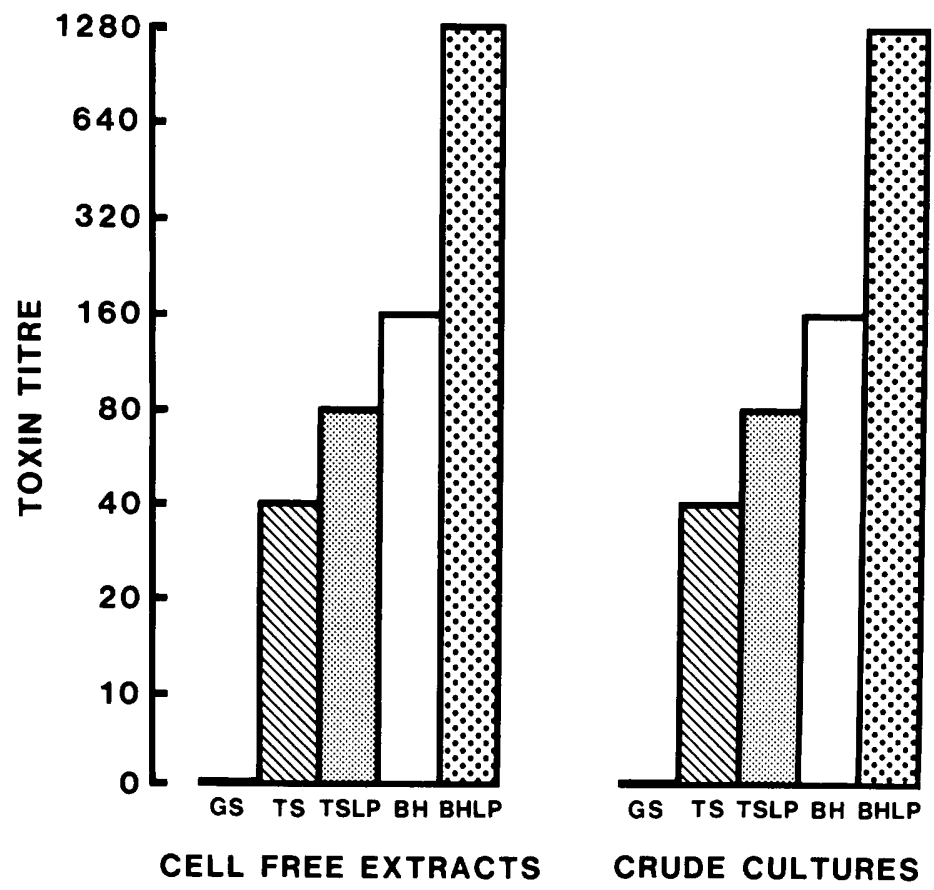

FIG.-Production of heat-labile enterotoxin by the $\mathrm{LT}^{+}$strain of $E$. coli in five media. For key to abbreviations see Methods section. 


\section{RESULTS}

The figure shows the toxin titres produced by the $\mathrm{LT}^{+}$control organism in five media, as determined both in cell-free extracts and in crude cultures. Although bacterial growth was apparent, no detectable LT was produced in GS medium. No toxic effect was produced by any of the uninoculated media or by any cultures of the $\mathrm{LT}^{-}$control strain. No differences in toxin titre were noted between cell-free extracts and crude cultures.

We isolated LT-producing $E$. coli from the faecal samples of $7(4.7 \%)$ of the 150 patients; 6 of the 7 patients with positive samples were among the 58 who had returned from outside Europe (incidence $10 \cdot 3 \%$ ). The frequencies of $\mathrm{LT}^{+}$colonies among the LT-producing strains were: 4 out of 4,3 strains; 2 out of 4,3 strains; 1 out of 4,1 strain. In all cases the pooled cultures gave a positive result. In all cases identical results were obtained from cell-free extracts and from crude cultures.

Confirmation of positive findings. All isolates that caused toxic effects were checked for identity with the API 10S system (API Laboratory Products Ltd, Basingstoke, Hampshire RG22 6HY). Each culture was then retested in parallel with a portion of the same culture heated to $100^{\circ} \mathrm{C}$ for $5 \mathrm{~min}$ and cooled to $37^{\circ} \mathrm{C}$ before use, and with another portion that had been neutralised by adding $0.02 \mathrm{ml}$ of a $V$. cholerae antitoxin preparation (kindly supplied by Dr R. Thompson, Wellcome Biotechnology Ltd, Langley Court, Beckenham, Kent BR3 3BS) to $0.1 \mathrm{ml}$ of culture and incubating the mixture at $37^{\circ} \mathrm{C}$ for $5 \mathrm{~min}$.

The table shows the API 10S profiles and the serogroups of the seven LT-producing strains, and the countries from which the patients had come.

TABLE

Characteristics of LT-positive isolates of $E$. coli

\begin{tabular}{cccl}
\hline $\begin{array}{c}\text { Isolate } \\
\text { no. }\end{array}$ & $\begin{array}{c}\text { API 10S } \\
\text { profile }\end{array}$ & Serogroup & $\begin{array}{c}\text { Presumed } \\
\text { country of } \\
\text { origin }\end{array}$ \\
\hline 1 & 7005 & O 25 & Morocco \\
2 & 7305 & O 9 & Brazil \\
3 & 7005 & O 25 & Egypt \\
4 & 7204 & O 9 & Russia \\
5 & 7005 & O 6 & Tunisia \\
6 & 7305 & O 6 & Spain \\
7 & 7005 & O 6 & Bulgaria \\
\hline
\end{tabular}

\section{DisCUSSION}

Despite the importance of LT-producing strains of $E$. coli as a cause of traveller's diarrhoea (Gross, 1983; Gross et al., 1979; Rowe, 1979) their recognition can be accomplished in only a few diagnostic microbiology laboratories. Possible reasons for this include the drawbacks of currently recommended methods. Animal methods are expensive, time-consuming and difficult to reproduce accurately. Their continued use for the detection of LT would be difficult to justify.

LT is antigenic and various immunological methods for its detection have been developed (Evans and Evans, 1977; Serafim et al., 1979; Rönnberg and Wadström, 
1983). One of the more practicable and more widely appraised is the Biken test (Honda et al., 1981a). Despite the relative ease of these tests they suffer from the serious limitation that all require a specific high-titre antitoxin to highly purified $E$. coli LT. No such antitoxin is available commercially at present, and its production would almost certainly be beyond the scope of many routine diagnostic laboratories.

Tissue-culture methods are simple, can be made economical, and are more sensitive than either animal or immunological methods (Guerrant et al., 1974; Speirs et al., 1977). They do not require the high-titre specific reagents required by the latter. Earlier work on LT demanded the preparation of cell-free extracts of $E$. coli grown in complex chemically defined medium (Finkelstein et al., 1966), a procedure which has since been accepted as standard. Sack et al. (1971) found that $E$. coli produced low levels of LT in glucose syncase medium and found it necessary to concentrate the toxin before testing by a lengthy procedure involving high-speed centrifugation, membrane filtration, dialysis and ammonium sulphate precipitation. Although such procedures are necessary if animal inoculation is to be undertaken or purified toxin is to be produced, we have demonstrated that they are unnecessary for routine screening of clinical isolates by a tissue-culture method. Treatment of cultures with polymyxin and inclusion of streptomycin in the cell maintenance medium virtually eliminated problems with contamination which might be expected in work with crude cultures of E. coli.

A drawback with any tissue-culture work is cost. Two ways in which this can be reduced considerably are (1) by using fewer cell monolayers, and (2) by using smaller cell monolayers. A practicable means of achieving the first is to screen pooled cultures from several colonies. For this to be a reliable and effective procedure, the amount of toxin produced needs to be maximised. Lincomycin, an inhibitor of protein synthesis, optimally increases production of LT by $E$. coli if included in culture media at a concentration of $90 \mu \mathrm{g} / \mathrm{ml}$ (Levner, Wiener and Rubin, 1977). The subsequent treatment of cultures with polymyxin $100 \mu \mathrm{g} / \mathrm{ml}$ further increases toxin titre (Honda et al., 1981a). Our experiments with the $\mathrm{LT}^{+}$strain showed that when these two antibiotics were used with brain heart infusion broth, marked increases in toxin titre were obtained (see the figure). The most practicable way of reducing the cost is to use tissue-culture monolayers prepared in microplates. Although there are problems with such monolayers in virological use, their convenience and ease of handling make them suitable for toxin assays of this type.

The cytopathic effect produced by LT in Y1 mouse adrenal cells is easily seen, but specific confirmation that this effect is due to LT is desirable. Previous workers (Donta et al., 1974; Sack and Sack, 1975) suggested heat treatment as a sole confirmatory measure. We would suggest that threefold confirmation is required: biochemical identification of the isolate; demonstration of the heat-lability of the toxin; and demonstration of neutralisation of the cytopathic effect by $V$. cholerae antitoxin. As we have shown, such reliable identification of LT-producing $E$. coli is readily achievable in a routine diagnostic laboratory.

We thank Dr Sylvia Scotland and Dr B. Rowe of the Division of Enteric Pathogens, Central Public Health Laboratory, Colindale for supplying the control organisms and an initial supply of Y1 mouse adrenal cells, for serogrouping the isolates of $E$. coli and for helpful advice throughout this work. We also thank Dr D.C. Turk and other staff of the enteric pathogens section of Sheffield Public Health Laboratory for their cooperation, advice and encouragement. 


\section{REFERENCES}

De Mol P, Van Wijnendaele F, Hemelhof W, Corrazza Y. 1983 Possible field test for ST-producing Escherichia coli. Lancet 1:524-525.

Donta S T, Moon H W, Whipp S C 1974 Detection of heat-labile Escherichia coli enterotoxin with the use of adrenal cells in tissue culture. Science 183:334-336.

Evans D J, Evans D G 1977 Direct serological assay for the heat-labile enterotoxin of Escherichia coli using passive immune hemolysis. Infection and Immunity 16:604-609.

Finkelstein R A, Atthasampunna P, Chulasamaya M, Chardunmethee P 1966 Pathogenesis of experimental cholera: biologic activities of purified procholeragen A. Journal of Immunology 96:440-449.

Gross R J 1983 Escherichia coli diarrhoea. Journal of Infection 7:177-192.

Gross R J, Scotland S M, Rowe B 1979 Enterotoxigenic Escherichia coli causing diarrhoea in travellers returning to the United Kingdom. British Medical Journal 1:1463.

Guerrant R L, Brunton L L, Schnaitman T C, Rebhun L I, Gilman A G 1974 Cyclic adenosine monophosphate and alteration of Chinese hamster ovary cell morphology: a rapid, sensitive in-vitro assay for the enterotoxins of Vibrio cholerae and Escherichia coli. Infection and Immunity 10:320-327.

Honda T, Taga S, Takeda Y, Miwatani T 1981 $a$ Modified Elek test for detection of heat-labile enterotoxin of enterotoxigenic Escherichia coli. Journal of Clinical Microbiology 13:1-5.

Honda T, Akhtar Q, Glass R I, Golam Kibriya A K M 1981b A simple assay to detect Escherichia coli producing heat labile enterotoxin: results of a field study of the Biken test in Bangladesh. Lancet 2:609-610.

Levner M, Wiener F P, Rubin B A 1977 Induction of Escherichia coli and Vibrio cholerae enterotoxins by an inhibitor of protein synthesis. Infection and Immunity 15:132-137.

Rönnberg B, Wadström T 1983 Rapid detection by a coagglutination test of heat-labile enterotoxin in cell lysates from blood agar-grown Escherichia coli. Journal of Clinical Microbiology 17:1021-1025.

Rowe B 1979 The role of Escherichia coli in gastroenteritis. Clinics in Gastroenterology 8:625-644.

Sack R B, Gorbach S L, Banwell J G, Jacobs B, Chatterjee B D, Mitra R C 1971 Enterotoxigenic Escherichia coli isolated from patients with severe cholera-like disease. Journal of Infectious Diseases 123:378-385.

Sack D A, Sack R B 1975 Test for enterotoxigenic Escherichia coli using Y1 mouse adrenal cells in miniculture. Infection and Immunity 1:334-336.

Serafim M B, Pestana de Castro A F, Lemos dos Reis M H, Trabulsi L R 1979 Passive immune hemolysis for detection of heat-labile enterotoxin produced by Escherichia coli isolated from different sources. Infection and Immunity 24:606-610.

Speirs J I, Stavric S, Konowalchuk J 1977 Assay of Escherichia coli heat-labile enterotoxin with Vero cells. Infection and Immunity 16:617-622. 